\title{
Penambahan Berbagai Jenis Pupuk Organik dan Pupuk Hayati terhadap Produktivitas dan Mutu Benih Kedelai (Glycine max.L.)
}

\author{
Application of Organic Fertilizer and Biofertilizer on Productivity and Quality of Soybean Seed (Glycine \\ $\max . L$. \\ Rifka $^{1}$, Memen Surahman ${ }^{1 *}$, Suryo Wiyono ${ }^{2}$ \\ ${ }^{1}$ Departemen Agronomi dan Hortikultura, Fakultas Pertanian, Institut Pertanian Bogor \\ (Bogor Agricultural University) \\ Telp. \& Faks.62-251-8629353 e-mail agrohort@apps.ipb.ac.id \\ ${ }^{2}$ Departemen Proteksi Tanaman, Fakultas Pertanian, Institut Pertanian Bogor (Bogor Agricultural \\ University), Jl. Meranti, Kampus IPB Darmaga, Bogor 16680, Indonesia \\ Telp. 62-251-8629364 e-mail protanipb@ipb.ac.id \\ *Penulis Korespondensi : msurahm@gmail.com
}

Disetujui : 21 Mei 2018 / Published Online September 2019

\begin{abstract}
This research aims to find the type of organic fertilizer for increasing the productivity and seed quality of soybean seeds (Glycine max L.). The research was conducted at Leuwikopo Experimental Field of Bogor Agricultural University, Dramaga, Bogor from December 2017 to April 2018. Soil type is Latosol. The research design was Randomized Complete Block Design with one factor and four replications. The factor was the type of fertilizer which consists of 6 levels, namely P0 (unfertilized), P1 (chemical Fertilizer), P2 (grilled Ash), P3 (Bio-organic), P4 (Liquid organic fertilizer) and P5 (Plant Growth Promoting Rhizobacteria (PGPR)). Seed quality testing was conducted in the Seed Testing and Storage Laboratory. The seed quality testing consists of germination, vigor index, maximum growth potential, seedling dry weight and 100 seeds weight. The results of the research showed that the organic fertilizer had not effect to vegetative growth (plant height, number of branches, number of leaves) but significantly effected on germination percentage and number of root nodules. Type of fertilizer significantly effected on the production of soy bean and dry 100 seeds weight but it had not effect on the number of pods per plant, number of contents pods, pod content weight, pod seed weight, number of seed per plant, number of productive branches, and root weight. Type of fertilizer did not effect on some variable of seed quality germination, vigor index, maximum growth potential and dry weight of seedlings. The best treatment of organic fertilizer that produces the hight production is PGPR treatment with dose of $10 \mathrm{~g} \mathrm{~kg}^{-1}$ seed. All organic fertilizer treatments had not effect on the physiological quality of seeds.
\end{abstract}

Keywords: organic fertilizer, PGPR, physiology, seed production

\begin{abstract}
ABSTRAK
Penelitian ini bertujuan mendapatkan jenis pupuk organik untuk meningkatkan produktivitas dan mutu benih tanaman kedelai (Glycine max L.). Penelitian dilaksanakan di Kebun Percobaan Leuwikopo, Institut Pertanian Bogor, Dramaga, Bogor pada bulan Desember 2017-April 2018. Jenis tanah Kebun Percobaan Leuwikopo yaitu latosol. Rancangan perlakuan yang digunakan adalah faktorial satu faktor dalam rancangan lingkungan kelompok lengkap teracak dengan empat ulangan. Faktor yang diamati adalah jenis pupuk yang terdiri atas enam taraf yaitu perlakuan P0 (tanpa pupuk anorganik dan pupuk organik), P1 (Pupuk anorganik), P2 (Abu sekam bakar), P3 (Bio organik), P4 (Pupuk organik cair) dan P5 (Plant growth Promoting Rhizobacteria (PGPR)). Pengujian mutu benih hasil produksi dilaksanakan di Laboratorium Pengujian dan Penyimpanan Benih pada bulan April 2018. Pengujian tersebut terdiri atas pengujian daya berkecambah, indeks vigor benih, potensi tumbuh maksimum, berat kering kecambah normal dan bobot 100 butir benih. Hasil penelitian menunjukan bahwa perlakuan pupuk organik tidak berpengaruh terhadap komponen pertumbuhan vegetatif seperti tinggi tanaman, jumlah cabang per tanaman, dan jumlah daun terkecuali daya tumbuh dan jumlah bintil akar. Perlakuan pupuk memberikan pengaruh nyata terhadap produksi kedelai dan bobot 100 butir benih tetapi tidak berpengaruh nyata terhadap jumlah polong per tanaman, jumlah polong isi, bobot polong isi, bobot biji tanpa polong, jumlah butir per tanaman, jumlah cabang produktif, dan bobot akar. Perlakuan pupuk tidak memberikan pengaruh nyata pada komponen pengujian mutu benih yakni variabel daya berkecambah, indeks vigor, potensi tumbuh maksimum dan bobot kering kecambah normal. Penambahan pupuk organik yang menghasilkan produksi terbaik yaitu perlakuan PGPR dengan dosis $10 \mathrm{~g} \mathrm{~kg}^{-1}$ benih. Semua perlakuan pupuk organik tidak berpengaruh terhadap mutu fisiologis benih.
\end{abstract}

Kata kunci : fisiologi benih, PGPR, produksi benih, pupuk organik 


\section{PENDAHULUAN}

Kedelai (Glycine max L.) merupakan salah satu komoditas utama kacang-kacangan yang sangat penting dalam memenuhi kebutuhan pangan nasional. Produksi kedelai secara nasional sebesar 885.85 ribu ton biji kering pada tahun 2016 dan menurun sebesar $8.06 \%$ dibandingkan pada tahun 2015. Produktivitas kedelai pada tahun 2016 mencapai 1.10 juta ton ha ${ }^{-1}$ dan pada tahun 2016 mencapai 1.13 juta ton $\mathrm{ha}^{-1}$ (Ditjen Tanaman Pangan, 2016). Produksi kedelai dalam negeri hanya mampu memenuhi $25 \%$ atau 625000 ton dari total kebutuhan kedelai dan selebihnya dipenuhi dengan cara impor sebesar $75 \%$ atau 1.875 juta ton $^{-1}{ }^{-1}$ (Kementerian Pertanian, 2015). Kendala yang dihadapi dalam produksi kedelai di Indonesia yaitu produktivitasnya rendah, harga relatif murah, luas areal tanam semakin menurun, dan lahan marjinal yang sulit untuk ditanami kedelai. Hal ini dapat berakibat pendapatan petani menjadi menurun dan akhirnya petani enggan menanam kedelai. Petani lebih memilih komoditas lain yang lebih menguntungkan. Selain itu, produksi kedelai yang rendah tidak dapat mensuplai kebutuhan dalam negeri dan akhirnya impor.

Selain itu, pemupukan anorganik dapat memicu pertumbuhan dan produktivitas kedelai dengan dosis optimal. Tetapi hasil berbagai penelitian selama ini pemupukan anorganik tanpa pemberian pupuk organik tidak mampu mendongkrak produktivitas kedelai. Selain itu, pemupukan anorganik secara terus menerus dapat berdampak negatif terhadap kesuburan tanah dan produktivitas tanaman dapat menurun. Salah satu upaya peningkatan produktivitas dan mutu benih kedelai adalah dengan pemberian pupuk organik. Pupuk organik cair dapat diaplikasikan langsung pada tanah maupun melalui daun. Manfaat pupuk organik cair antara lain merangsang pertumbuhan dan perkembangan akar, tanaman lebih tahan terhadap hama dan penyakit dan stres, meningkatkan perkembangan dan pertumbuhan tanaman secara keseluruhan serta memperbaiki kualitas hasil panen (Adisarwanto, 2008).

Pupuk bio organik mengandung mikroba sebagai biofertilizer, hormon pertumbuhan dan asam amino yang dibutuhkan tanaman (Suswono, 2010). Manfaat pupuk bio organik antara lain dapat memacu pertumbuhan tanaman, memperkuat batang tanaman, meningkatkan daya tahan terhadap serangan hama dan penyakit, serta dapat mengurangi dosis pupuk anorganik hingga 50\% (Suswono, 2010). Pemberian abu bakar diharapkan dapat memperbaiki fungsi fisiologi tanaman dan meningkatkan ketahanan tanaman terhadap serangan hama, penyakit dan kerebahan tanaman karena mengandung unsur silikat yang bermanfaat untuk tanaman kedelai (Siregar et al., 2017).

Kelompok bakteri Plant Growth Promoting Rhizobacteri (PGPR) merupakan kelompok bakteri yang mampu menambat nitrogen dari udara maupun dalam tanah. PGPR juga mampu melarutkan $\mathrm{P}$ yang terikat dan mampu memproduksi hormon tumbuh (IAA) sehingga pertumbuhan dan produksi kedelai semakin meningkat. Selain itu, bakteri PGPR dapat menghambat patogen melalui sintesis senyawa antibiotik sebagai kontrol biologis (Saraswati dan Sumarsono, 2008). Bakteri PGPR juga dapat menambah nodulasi dan jumlah perakaran tanaman kedelai sehingga berpengaruh terhadap produksi kedelai. Penelitian ini menggunakan bakteri Rhizobium sp., Bacillus polymixa, dan Pseudomonas flourescens. Penggunaan pupuk organik dan pupuk hayati diharapkan dapat menunjang pertumbuhan tanaman kedelai sehingga produktivitas dan mutu benihnya dapat meningkat.

\section{BAHAN DAN METODE}

Penelitian dilaksanakan mulai bulan Desember 2017 hingga bulan April 2018 di Kebun Percobaan IPB Leuwikopo, Dramaga, Bogor. Lokasi penelitian berada pada ketinggian $250 \mathrm{~m}$ dpl dengan jenis tanah Latosol. Pengujian mutu benih dilaksanakan pada bulan April 2018 di Laboratorium Pengujian dan Penyimpanan Benih, Departemen Agronomi dan Hortikultura, Fakultas Pertanian, Institut Pertanian Bogor. Bahan tanaman yang digunakan untuk penelitian adalah benih kedelai varietas Demas 1. Bahan lain yang digunakan yaitu pupuk organik cair dengan

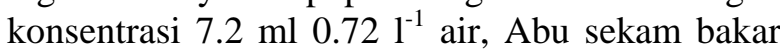
dengan dosis 10 ton ha ${ }^{-1}$, Bio organik yang dibuat sendiri dari pupuk kandang yang disemprot bakteri Acckw5 dan P24 dengan dosis 10 ton $\mathrm{ha}^{-1}$, PGPR dengan dosis $10 \mathrm{~g} \mathrm{~kg}^{-1}$ benih, pupuk kimia yang terdiri atas Urea, Phosphat dan KCL dan insektisida butiran (furadan) dengan dosis $20 \mathrm{~kg}$ $\mathrm{ha}^{-1}$.

Penelitian menggunakan rancangan kelompok lengkap teracak (RKLT). Perlakuan yang digunakan adalah faktor tunggal dengan ukuran petakan $3 \mathrm{~m} \times 3 \mathrm{~m}$. Petakan dibagi sub petakan sebagai ulangan. Perlakuan yang diterapkan pada penelitian ini terdiri atas 6 perlakuan dengan 4 ulangan, sehingga didapatkan 24 satuan percobaan. Perlakuan tersebut yaitu: P0 (kontrol, tanpa pupuk anorganik dan pupuk 
organik), P1 (pupuk anorganik yaitu pupuk urea dengan dosis $25 \mathrm{~kg}$ urea $\mathrm{ha}^{-1}$, pupuk phosphat dengan dosis $200 \mathrm{~kg} \mathrm{SP} 36 \mathrm{ha}^{-1}$,dan KCL dengan dosis $150 \mathrm{~kg} \mathrm{KCL} \mathrm{ha-1}{ }^{1}$ ), P2 (abu sekam bakar dosis 10 ton $\mathrm{ha}^{-1}$ dengan cara diaplikasikan ke tanah sebelum tanam), P3 (bio organik dosis 10 ton $\mathrm{ha}^{-1}$ dengan cara diaplikasikan ke tanah sebelum tanam), P4 (pupuk organik cair dengan 5 kali aplikasi dengan cara disemprotkan ke bagian daun dari tanaman). Satu kali aplikasi menggunakan dosis $21 \mathrm{ha}^{-1}$, dan P5 (Plant Growth Promoting Rhizobacteri (PGPR) dosis $10 \mathrm{~g} \mathrm{~kg}^{-1}$ benih dengan cara pelembaban benih sebelum ditanam.

Pelaksanaan penelitian diawali dengan pembuatan pupuk bio organik yang dibuat satu bulan sebelum tanam. Bahan dasar pembuatan pupuk bio organik yaitu pupuk kandang, air dan mikroba. Kegiatan selanjutnya yaitu persiapan semua pupuk organik yang akan digunakan serta persiapan lahan. Kegiatan selanjutnya yaitu perlakuan benih dengan abu sekam bakar, dan air + POC yaitu bio hara plus dengan perbandingan 1:3:5. Lahan yang digunakan untuk penelitian dibersihkan dari gulma. Lahan dibuat petakan berukuran $3 \mathrm{~m}$ x $3 \mathrm{~m}$. Lahan yang sudah dibuat petakan tersebut kemudian diberi label perlakuan. Petakan P2 dan P3 di ditebarkan dan dibenamkan ke dalam lahan seminggu sebelum tanam. Sedangkan petakan P4 disemprot POC empat hari sebelum tanam dengan konsentrasi $7.2 \mathrm{ml} 0.721^{-1}$ air dan dosis $21 \mathrm{ha}^{-1}$.

Penanaman dilakukan dengan mengisi lubang tanam yang telah dibuat dengan tiga benih kedelai. Pemupukan anorganik dilakukan satu minggu setelah penanaman dengan cara aplikasi dialur. Pemupukan pupuk organik cair dilakukan sebelum penanaman dan pada saat tanaman berumur 15 HST, 28 HST dan 42 HST. Benih yang tidak tumbuh, dilakukan penyulaman pada saat satu Minggu Setelah Tanam (MST), selain melakukan penyulaman juga dilakukan pemasangan ajir pada tanaman contoh. Pemeliharaan tanaman meliputi pengairan, pengendalian hama, penyakit dan gulma. Pengendalian gulma atau penyiangan dilakukan setiap satu minggu sekali sedangkan untuk pengendalian hama dan penyakit dilakukan apabila terdapat gangguan hama dan penyakit.

Pemanenan dilakukan saat warna daun, batang, dan polong sudah menguning kecoklatan atau kering. Pemanenan dilakukan dengan cara manual. Polong yang telah dipanen kemudian dijemur. Polong yang telah kering kemudian dipisahkan dengan benihnya. Benih yang telah terpisah dengan polongnya kemudian dilakukan pengeringan kembali untuk mencapai kadar air yang aman untuk disimpan. Benih kedelai selanjutnya dilakukan pengujian mutu. Pengujian mutu yang dilakukan yaitu pengujian daya berkecambah, bobot kering kecambah normal, indeks vigor benih dan potensi tumbuh maksimum. Komponen variabel pertumbuhan vegetatif yang diamati meliputi daya tumbuh, tinggi tanaman, jumlah daun, jumlah cabang, dan jumlah bintil akar. Komponen variabel produksi yang diamati meliputi produksi, jumlah polong per tanaman, Jumlah polong isi, Bobot biji dengan polong, Bobot biji tanpa polong, Jumlah butir per tanaman, Hasil biji per tanaman, Bobot biji per tanaman dan Bobot 100 butir. Data yang diperoleh dianalisis untuk mengetahui pengaruh perlakuan pupuk organik dan pupuk hayati dengan melakukan uji F pada taraf nyata $\alpha=5 \%$. Apabila terdapat pengaruh nyata terhadap parameter yang diamati maka dilakukan uji lanjut jarak berganda Duncan Multiple Range Test (DMRT) pada taraf 5\%. Data hasil pengamatan diolah dengan menggunakan program Statistical Analysis System (SAS).

\section{HASIL DAN PEMBAHASAN}

\section{Kondisi Pertanaman}

Rata-rata curah hujan di lokasi penelitian yaitu $213 \mathrm{~mm}$ bulan $^{-1}$. Kebutuhan air minimal untuk pertanaman kedelai sebesar $100 \mathrm{~mm}^{-1}$ bulan $^{-}$ 1 , sehingga curah hujan pada lahan penelitian sudah memenuhi persyaratan tersebut, pada bulan Maret $2018(122.70 \mathrm{~mm})$ kondisi curah hujan mendukung untuk kegiatan pemanenan dan pengeringan benih. Suhu rata-rata per bulan yaitu $25.75^{\circ} \mathrm{C}$ dan telah sesuai dengan syarat tumbuh tanaman kedelai yakni sekitar $23-30{ }^{\circ} \mathrm{C}$. Kelembaban rata-rata di lokasi penelitian yaitu $83 \%$. Kelembaban tersebut terlalu tinggi jika dibandingkan dengan syarat tumbuh tanaman kedelai yang hanya sebesar 60-70\% (Balai Pengkajian Teknologi Pertanian, 2009).

Tanah tempat penelitian merupakan jenis tanah Latosol. Menurut Rukmana dan Yuniarsih (1996), kedelai dapat tumbuh dengan baik pada jenis tanah Aluvial, Regosol, Latosol, dan Andosol. Kebun percobaan ini memiliki jenis tanah dengan $\mathrm{pH}$ yang termasuk kriteria masam. Menurut Sumarno dan Manshuri (2007), pH optimal bagi pertumbuhan kedelai yaitu 6.0-6.5. pH yang tidak optimal menyebabkan aktifitas mikroba tidak efektif sehingga penguraian bahan organik dan ketersediaan hara juga tidak efektif. Kedelai dapat tumbuh optimal dengan penyinaran matahari minimal 10 jam per hari atau $83 \%$ per hari sedangkan saat penelitian lama penyinaran matahari terlalu singkat yaitu 5-6 jam per hari 
atau rata-rata $49.80 \%$. Hal ini mengakibatkan tanaman menjadi lebih tinggi dan daunnya semakin banyak sehingga fase vegetatif kedelai semakin lama. Menurut Anggraeni (2010), intensitas penyinaran yang hanya $50 \%$ dapat menekan pertumbuhan kedelai, mengurangi jumlah cabang, buku dan polong sehingga menurunkan hasil biji hingga $60 \%$.

Kondisi pertanaman selama penelitian teridentifikasi mengalami serangan hama dan penyakit sehingga dilakukan pengendalian secara kimiawi. Fase awal pertumbuhan dan sebelum penyulaman, benih yang tidak tumbuh terserang patogen Sclerotium rolfsii. Hama menyerang tanaman pada fase vegetatif yaitu 4 MST hingga 7 MST. Hama yang dominan pada tanaman kedelai adalah belalang, ulat bulu, ulat penggulung daun (Lamprosema indicata) dan ulat grayak. Pengendalian dilakukan dengan dengan memberikan insektisida berbahan aktif sipermetrin ke seluruh bagian tanaman. Penelitian ini tidak mengamati petak perlakuan terbaik yang tidak terserang hama dan penyakit karena hanya mengamati tanaman yang terserang dengan pengamatan visual saja. Penyiangan gulma dilakukan dari 2 MST hingga menjelang panen. Jenis gulma yang terdapat pada areal pertanaman terdiri dari gulma golongan teki (Cyperus rotundus, Eleusine indica), daun lebar (Borreria alata, dan Ageratum conyzoides), dan rumput (Rottboellia exaltata, Imperata cyllindrica). Pengendalian gulma dilakukan dengan cara manual menggunakan cangkul dan kored.

\section{Pengaruh Penambahan Pemupukan Organik dan Anorganik terhadap Pertumbuhan Vegetatif Tanaman Kedelai}

Hasil analisis ragam menunjukkan bahwa perlakuan pupuk tidak memberikan pengaruh nyata terhadap tinggi tanaman, jumlah daun, dan jumlah cabang tanaman kedelai. Perlakuan pupuk memberikan pengaruh nyata terhadap daya tumbuh dan jumlah bintil akar (Tabel 1).

Tabel 1. Rekapitulasi sidik ragam komponen pertumbuhan vegetatif tanaman kedelai

\begin{tabular}{lcc}
\hline Variabel & $\begin{array}{c}\text { Hasil Analisis } \\
\text { Ragam }\end{array}$ & $\begin{array}{c}\text { Koefisien } \\
\text { Keragaman (\%) }\end{array}$ \\
\hline
\end{tabular}

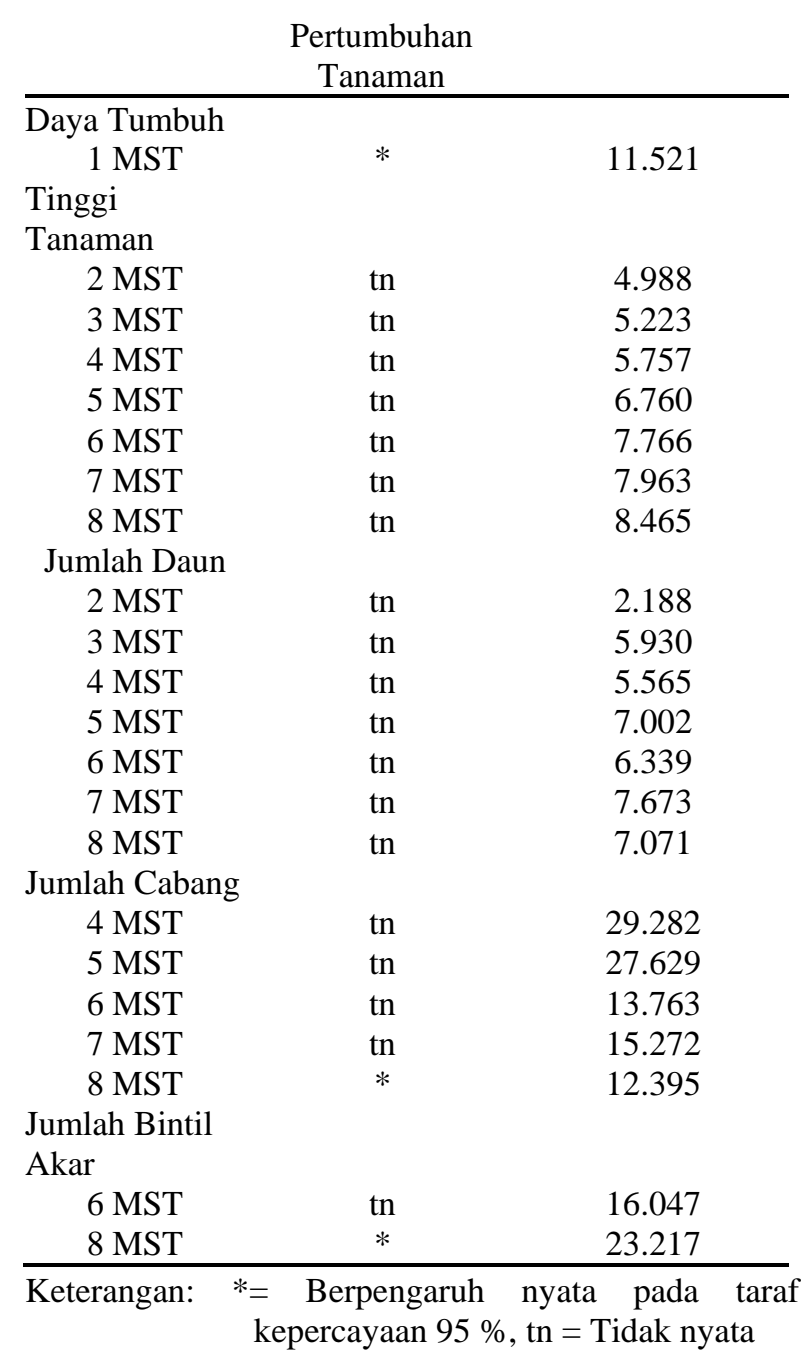

\section{Daya Tumbuh}

Perlakuan berbagai macam pupuk organik memberikan pengaruh nyata terhadap daya tumbuh. Berdasarkan hasil percobaan, daya tumbuh paling besar yaitu perlakuan bio organik (Tabel 2). Perlakuan P3 berbeda nyata dengan P1, P2, dan P5. Pupuk bio organik dibuat dari campuran pupuk kandang dan bakteri Acckw5 dan P24 sehingga kandungan bahan organik dan mikroorganisme yang terkandung didalamnya lebih tinggi dibandingkan dengan pupuk organik yang lain. Hal tersebut menyebabkan kemampuan pupuk bio organik dalam memperbaiki sifat tanah lebih baik dari pupuk organik yang lain.

Tabel 3. Rata-rata tinggi tanaman dan jumlah daun kedelai pada berbagai perlakuan kombinasi pupuk

\begin{tabular}{|c|c|c|c|c|c|c|c|c|c|c|c|c|c|c|}
\hline \multirow{3}{*}{$\begin{array}{c}\text { Perlakuan } \\
\text { Pupuk }\end{array}$} & \multicolumn{7}{|c|}{ Tinggi Tanaman $(\mathrm{cm})$} & \multicolumn{7}{|c|}{ Jumlah Daun } \\
\hline & \multicolumn{14}{|c|}{ Minggu Ke- } \\
\hline & 2 & 3 & 4 & 5 & 6 & 7 & 8 & 2 & 3 & 4 & 5 & 6 & 7 & 8 \\
\hline $\mathrm{P} 0$ & 12.65 & 17.67 & 25.30 & 34.79 & 45.54 & 59.61 & 68.65 & 3.12 & 4.67 & 6.70 & 8.45 & 8.68 & 10.50 & 12.03 \\
\hline P1 & 12.15 & 16.74 & 25.54 & 36.74 & 47.51 & 64.63 & 75.79 & 2.95 & 4.37 & 6.87 & 9.02 & 9.30 & 10.95 & 12.86 \\
\hline $\mathrm{P} 2$ & 12.53 & 17.22 & 25.96 & 35.74 & 46.72 & 61.18 & 73.49 & 3.03 & 4.52 & 6.77 & 8.81 & 8.91 & 10.66 & 12.75 \\
\hline P3 & 12.53 & 17.68 & 25.74 & 36.28 & 47.60 & 63.45 & 75.61 & 3.07 & 4.50 & 6.78 & 8.93 & 8.85 & 10.37 & 12.42 \\
\hline P4 & 12.48 & 17.22 & 25.10 & 35.24 & 46.46 & 59.87 & 73.40 & 3.07 & 4.48 & 6.76 & 8.80 & 9.58 & 11.08 & 13.23 \\
\hline P5 & 11.99 & 16.99 & 24.85 & 34.08 & 45.06 & 58.16 & 70.83 & 2.90 & 4.36 & 6.93 & 8.63 & 9.03 & 11.25 & 13.06 \\
\hline
\end{tabular}


Keterangan : P0 : Kontrol, P1 : Pupuk anorganik, P2 : Abu sekam, P3 : Bio organik, P4 : Pupuk Organik Cair, P5 :PGPR

Selain itu, mikroba dalam bio organik tersebut juga dapat menekan populasi patogen dalam tanah sehingga pertumbuhannya tidak terganggu (Suswono, 2010).

Persentase daya tumbuh tanaman (Tabel 2) berdasarkan perlakuan pupuk organik dan pupuk hayati diperoleh bahwa daya tumbuh tanaman kedelai tergolong cukup baik berkisar dari 54.12$80.09 \%$. Faktor yang mempengaruhi daya tumbuh benih tersebut seperti kondisi tanah, cuaca, ketersediaan air, dan faktor biotik lainnya. Kondisi genetik, viabilitas dan vigor dari benih yang masih baik juga mempengaruhi daya tumbuh benih dilapangan.

Tabel 2. Persentase daya tumbuh pada berbagai perlakuan pupuk

\begin{tabular}{|c|c|}
\hline Perlakuan Pupuk & Persentase $(\%)$ \\
\hline P0 (kontrol) & $66.38 \mathrm{ab}$ \\
\hline (pupuk anorganik) & $54.12 \mathrm{~b}$ \\
\hline (abu sekam bakar) & $64.07 \mathrm{ab}$ \\
\hline (bio organik) & $80.09 \mathrm{a}$ \\
\hline P4 (pupuk organik cair) & $76.62 \mathrm{a}$ \\
\hline (PGPR) & $57.82 \mathrm{~b}$ \\
\hline
\end{tabular}

Keterangan : Angka-angka yang diikuti oleh huruf yang berbeda pada kolom yang sama, berbeda nyata pada taraf uji DMRT 5\%.

Daya tumbuh P1 dan P5 tergolong rendah dibandingkan dengan perlakuan lainnya. Hal ini disebabkan ketersediaan air yang rendah dan hanya dicukupi dengan penyiraman setiap hari. Air dibutuhkan dalam jumlah yang banyak pada awal pertumbuhan untuk merombak cadangan makanan pada benih agar dapat menjalankan fase perkecembahan dengan baik sehingga menjadi tanaman yang baik dan normal. Ai dan Ballo (2010), menyatakan bahwa air berperan penting mengaktifkan sel-sel embrionik pada biji, melunakkan kulit biji, membantu mengembangnya embrio dan endosperm, dan media pengangkutan makanan dari endosperm atau kotiledon ke titik tumbuh.

\section{Tinggi Tanaman dan Jumlah Daun}

Perlakuan berbagai jenis pupuk organik tidak berpengaruh nyata terhadap tinggi tanaman (Tabel 3). Abu sekam bakar tidak berpengaruh nyata diduga dosisnya tidak cukup untuk mempengaruhi pertumbuhan tanaman. Pupuk bio organik juga tidak memberikan pengaruh nyata terhadap tinggi tanaman diduga dosisnya yang belum cukup untuk mempengaruhi pertumbuhan. Penelitian Wahyuni (2009) yang menyatakan bahwa pemberian POC NASA pada konsentrasi yang berbeda tidak memberikan pengaruh yang nyata terhadap tinggi tanaman PGPR juga tidak berpengaruh nyata diduga dosisnya belum cukup untuk mempengaruhi pertumbuhan.

Perlakuan penambahan pupuk organik tidak memberikan pengaruh yang nyata terhadap jumlah daun mulai dari minggu awal pengamatan sampai minggu akhir pengamatan. Jumlah daun setiap minggunya mengalami peningkatan tetapi peningkatan tidak terlalu berbeda sehingga hasilnya tidak berbeda nyata antar perlakuan. Hal ini tidak sesuai dengan penelitian Gani et al. (2013) , yang menyatakan bahwa perlakuan pupuk kandang memberikan pengaruh nyata terhadap jumlah daun dengan dosis 20 ton ha ${ }^{-1}$. Hal ini diduga karena penelitian ini penggunaan dosis yang lebih rendah sebanyak 10 ton $\mathrm{ha}^{-1}$ sehingga tidak memberikan pengaruh nyata terhadap jumlah daun.

Aplikasi pupuk organik cair melalui daun juga tidak memberikan pengaruh nyata terhadap jumlah daun meskipun aplikasinya bertahap. Hal ini sesuai dengan penelitian Sukmana (2017), menyatakan bahwa perlakuan kombinasi pupuk daun tidak berpengaruh nyata terhadap pertambahan jumlah daun sagu. Hal ini disebabkan oleh intensitas cahaya yang kurang maksimal dan naungan. Naungan mengakibatkan asimilat yang dihasilkan dari proses fotosintesis berkurang karena intensitas cahaya yang diterima berkurang.

Pertumbuhan jumlah daun pada aplikasi abu sekam bakar memperoleh hasil lebih tinggi dibandingkan kontrol pada umur 4 MST hingga 8 MST meskipun tidak berbeda secara statistik. Jumlah daun kedelai masing-masing dapat dilihat pada Tabel 6. Hal ini sesuai dengan penelitian Eliazar dan Aziz (2015) bahwa pemberian abu sekam dapat meningkatkan jumlah daun pada tanaman kemuning. Hal ini diduga karena unsur $\mathrm{K}$ yang terkandung dalam abu sekam bakar. Ketersediaan unsur hara $\mathrm{K}$ yang tinggi dapat meningkatkan aktivitas fotosintesis sehingga energi yang tersedia bagi tanaman tinggi (Suminarti, 2010).

\section{Jumlah Cabang dan Jumlah Bintil Akar}

Perlakuan penambahan pupuk organik memberikan pengaruh nyata terhadap jumlah cabang pada 8 MST tetapi tidak berpengaruh nyata terhadap jumlah cabang pada 4 MST, 5 MST, 6 MST, dan 7 MST. Jumlah cabang tiap minggunya cenderung mengalami peningkatan walaupun tidak berbeda nyata (Tabel 4). Jumlah cabang juga cenderung mengalami penurunan pada P5 walaupun tidak berbeda nyata. Hal ini diduga karena jumlah cabang tersebut tidak 
mengalami perkembangan dari minggu sebelumnya. Menurut Susanto dan Sundari (2010), intensitas sinar matahari yang berkurang menyebabkan tanaman tumbuh lebih tinggi, ruas antar buku lebih panjang, jumlah daun dan cabang lebih sedikit, jumlah polong sedikit dan ukuran biji semakin kecil. Perlakuan pupuk organik dan hayati berpengaruh nyata terhadap jumlah cabang pada 8 MST. Jumlah cabang paling tinggi terdapat pada perlakuan P3 (bio organik) meskipun tidak berbeda nyata dengan P1 dan P5. Hal ini diduga karena pengaruh penambahan pupuk kandang dan bakteri yang dapat memperbaiki sifat fisik, kimia dan biologi tanah. Perlakuan pupuk berpengaruh nyata terhadap jumlah bintil akar. Jumlah bintil akar pada perlakuan P0 lebih sedikit daripada perlakuan lain. Hal ini diduga karena tidak ada penambahan pupuk organik maupun anorganik sehingga jumlah bintil tidak mengalami pertambahan. Menurut Rosmarkam dan Yuwono (2002), Penambahan pupuk urea pada saat awal penanaman dapat meningkatkan efektifitas bakteri Rhizobium dalam menambat N2 udara sehingga dapat meningkatkan jumlah bintil akar. Perlakuan P5 yang menggunakan PGPR juga memiliki jumlah bintil akar paling banyak. Hal ini terjadi karena Rhizobium dapat meningkatkan jumlah bintil akar dengan penambatan nitrogen yang selanjutnya akan membentuk klorofil dan enzim sehingga mampu meningkatkan fotosintesis (Surtiningsih et al., 2009).

\section{Pengaruh Penambahan Pupuk Organik Terhadap Komponen Produksi Kedelai}

Analisis ragam pengaruh perlakuan pupuk organik berpengaruh nyata terhadap produksi per petak dan bobot 100 butir, tetapi tidak memberikan pengaruh nyata terhadap jumlah polong per tanaman, jumlah polong isi, bobot polong isi, bobot biji tanpa polong, jumlah butir per tanaman, jumlah cabang produktif, dan bobot akar. Perlakuan tidak memberikan pengaruh nyata terhadap bobot akar. Hal ini berbeda dengan penelitian Wahyuni (2009) yang menyatakan bahwa pemberian POC memberikan pengaruh nyata terhadap penambahan bobot akar tanaman kedelai. Konsentrasi yang diberikan pada penelitian tersebut $6 \mathrm{ml} \mathrm{L}^{-1}$ air sedangkan pada penelitian ini menggunakan konsentrasi yang relatif lebih rendah dan berbeda setiap tahap. Bobot 100 butir dipengaruhi secara nyata oleh perlakuan pemupukan. Hal ini sesuai dengan hasil penelitian Lingga dan Marsono (2000) yang menyatakan bahwa semakin banyak unsur hara dan pupuk yang diberikan maka akan meningkatkan berat 100 biji sesuai yang diharapkan apabila tidak melebihi batas optimum dari konsentrasi yang dianjurkan.

Tabel 4. Rata- rata jumlah cabang dan jumlah bintil tanaman kedelai pada berbagai perlakuan pupuk organik

\begin{tabular}{lccccccc}
\hline Perlakuan & \multicolumn{4}{c}{ Jumlah Cabang (MST) } & \multicolumn{3}{c}{ Jumlah Bintil (MST) } \\
\cline { 2 - 8 } Pupuk & 4 & 5 & 6 & 7 & 8 & 6 & 8 \\
\hline P0 & 0.91 & 0.98 & 1.28 & 1.48 & $1.56 \mathrm{c}$ & 2.89 & $3.18 \mathrm{~b}$ \\
P1 & 1.06 & 1.13 & 1.29 & 1.58 & $1.94 \mathrm{ab}$ & 3.40 & $5.53 \mathrm{a}$ \\
P2 & 1.00 & 1.13 & 1.25 & 1.27 & $1.76 \mathrm{bc}$ & 3.31 & $4.09 \mathrm{ab}$ \\
P3 & 0.87 & 0.93 & 1.15 & 1.64 & $2.15 \mathrm{a}$ & 3.44 & $4.24 \mathrm{ab}$ \\
P4 & 1.16 & 1.18 & 1.27 & 1.45 & $1.55 \mathrm{c}$ & 2.93 & $4.11 \mathrm{ab}$ \\
P5 & 0.91 & 1.00 & 1.34 & 1.53 & $2.07 \mathrm{ab}$ & 3.24 & $4.72 \mathrm{a}$ \\
\hline
\end{tabular}

Keterangan : Angka-angka yang diikuti oleh huruf yang berbeda pada kolom yang sama berbeda nyata pada taraf uji DMRT $5 \%$

Tabel 5. Rata-rata komponen produksi kedelai pada berbagai perlakuan pupuk

\begin{tabular}{lccccccccc}
\hline $\begin{array}{l}\text { Perlakuan } \\
\text { Pupuk }\end{array}$ & $\begin{array}{c}\text { Produksi Per } \\
\text { Petak (g) }\end{array}$ & $\begin{array}{c}\text { Jumlah } \\
\text { Polong Per } \\
\text { Tanaman }\end{array}$ & $\begin{array}{c}\text { Jumlah } \\
\text { Polong Isi }\end{array}$ & $\begin{array}{c}\text { Bobot } \\
\text { Polong } \\
\text { Isi }\end{array}$ & $\begin{array}{c}\text { Bobot Biji } \\
\text { Tanpa } \\
\text { Polong }\end{array}$ & $\begin{array}{c}\text { Jumlah } \\
\text { Butir Per } \\
\text { Tanaman }\end{array}$ & $\begin{array}{c}\text { Jumlah } \\
\text { Cabang } \\
\text { Produktif }\end{array}$ & $\begin{array}{c}\text { Bobot } \\
\text { Akar }(\mathrm{g})\end{array}$ & $\begin{array}{c}\text { Bobot } \\
100 \\
\text { Butir }\end{array}$ \\
\hline P0 & $765.80 \mathrm{~b}$ & 37.10 & 31.50 & 5.86 & 2.78 & 48.50 & 1.80 & 2.00 & $5.47 \mathrm{~b}$ \\
P1 & $922.10 \mathrm{ab}$ & 42.20 & 37.80 & 7.34 & 3.58 & 54.10 & 1.70 & 2.84 & $6.24 \mathrm{ab}$ \\
P2 & $928.00 \mathrm{ab}$ & 41.90 & 36.30 & 7.35 & 3.56 & 59.60 & 1.80 & 2.68 & $7.20 \mathrm{a}$ \\
P3 & $913.09 \mathrm{ab}$ & 38.70 & 33.00 & 6.45 & 2.93 & 49.20 & 2.10 & 2.51 & $7.30 \mathrm{a}$ \\
P4 & $745.05 \mathrm{~b}$ & 38.10 & 32.70 & 6.03 & 2.88 & 52.80 & 2.20 & 2.74 & $6.78 \mathrm{a}$ \\
P5 & $993.04 \mathrm{a}$ & 42.10 & 37.20 & 6.89 & 3.85 & 64.10 & 2.40 & 2.88 & $7.40 \mathrm{a}$ \\
\hline Uji F & $*$ & tn & tn & tn & tn & tn & tn & tn & $*$ \\
\hline KK $(\%)$ & 12.82 & 17.41 & 18.48 & 21.10 & 22.53 & 23.91 & 24.59 & 16.48 & 11.27 \\
\hline
\end{tabular}

Keterangan : Angka-angka yang diikuti oleh huruf yang berbeda pada kolom yang sama, berbeda nyata pada taraf uji DMRT $5 \%, *=$ berpengaruh nyata pada taraf $5 \%, \mathrm{tn}=$ tidak berpengaruh nyata 
Perlakuan P5 menghasilkan produksi paling tinggi karena memiliki ukuran biji lebih besar dibandingkan perlakuan lainnya yang terlihat pada bobot 100 butir yang lebih besar (Tabel 5).

\section{Produksi Kedelai}

Hasil analisis menyatakan bahwa perlakuan P5 (PGPR) berbeda nyata dan memiliki nilai ratarata tertinggi produksi per petak dibandingkan dengan perlakuan lainnya. Perlakuan P5 merupakan perlakuan PGPR sehingga besar kemungkinan memperoleh produksi yang tinggi karena terdapat rizobakteri yang menambat nitrogen pada bintil akar dan mampu memproduksi hormon IAA yang dapat menginduksi akar tanaman secara langsung sehingga dapat meningkatkan laju pertumbuhan tanaman dan akan berpengaruh terhadap produksi (Maor et al., 2004). Penelitian ini menggunakan PGPR Rhizomax yang mengandung Pseudomonas fluorescens, Bacillus polymyxa, dan Rhizobium. Hal ini sesuai dengan pendapat Jordan (1984) yang menyatakan bahwa bakteri Rhizobium dapat menodulasi tanaman kedelai secara efektif. Penggunaan bakteri yang efektif dapat membantu pembentukan akar menjadi lebih baik dan pembentukan bintil akar semakin banyak sehingga pertumbuhan dan hasil produksi kedelai pun akan semakin meningkat (Hindersah dan Simarmata, 2004). Hal ini juga sesuai dengan penelitian Widawati et al. (2015) yang menyatakan bahwa penambahan PGPR pada tanaman kedelai dapat meningkatkan kesuburan tanah dengan meningkatkan populasi bakteri biofertilizer, menaikkan $\mathrm{pH}$ tanah , meningkatkan pembentukan bintil akar, serta berpengaruh positif pada pertumbuhan dan produksi kedelai di tanah marginal.

Perlakuan P1 dan P3 tidak berbeda nyata. Hal ini diduga karena penambahan pupuk bio organik pada P3 belum cukup untuk meningkatkan produksi walaupun produksinya lebih tinggi daripada P1 yang hanya menambahkan pupuk anorganik saja. Peningkatan produksi pada P3 diduga karena menambahkan pupuk bio organik dan pupuk anorganik sehingga unsur hara yang tersedia semakin meningkat. Perlakuan P2 dan P4 juga tidak berbeda nyata sedangkan produksi P2 yang menambahkan abu lebih tinggi produksinya daripada $\mathrm{P} 4$ yaitu pupuk organik cair.

Perlakuan P2 yang menggunakan abu sekam bakar lebih tahan terhadap hama dan penyakit dibandingkan dengan perlakuan P3 yang menggunakan bio organik sehingga produksi pada perlakuan P3 sedikit lebih rendah. Hal ini sesuai dengan penelitian Sundari (2015) yang menyatakan bahwa interaksi pemberian abu sekam dengan pupuk $\mathrm{P}$ dan $\mathrm{K}$ berpengaruh nyata terhadap produksi kedelai. Peningkatan produksi berasal dari unsur hara makro dan mikro tanaman yang terkandung dalam abu sekam bakar sehingga mampu meningkatkan $\mathrm{pH}$ tanah (Dharmaswara, 2012).

Perlakuan P0 berbeda nyata dan memperoleh hasil terendah dibandingkan perlakuan lainnya. Hal ini diduga karena tidak ada penambahan pupuk organik maupun anorganik sehingga unsur hara tidak mencukupi kebutuhan tanaman. pemupukan dan penambahan unsur hara dapat meningkatkan jumlah unsur hara dalam tanah yang dibutuhkan tanaman selama pertumbuhan sehingga tanaman dapat tumbuh optimal dan berproduksi maksimal (Marsono dan Sigit, 2000).

Perlakuan pupuk tidak memberikan pengaruh yang nyata terhadap jumlah polong per tanaman, jumlah polong isi, jumlah cabang produktif, bobot akar maupun bobot biji per tanaman. Pemberian pupuk organik belum mampu meningkatkan jumlah polong, jumlah cabang, bobot polong maupun bobot akar. Salah satu faktor penyebabnya yaitu unsur hara yang kurang dan penyerapan unsur hara kurang efektif sehingga berpengaruh terhadap proses pembentukan biji yang tidak maksimal. Faktor lainnya yaitu adanya serangan hama dan penyakit yang mengganggu proses pertumbuhan dan perkembangan polong dan biji karena ukuran polong yang kecil akan menghasilkan biji yang kecil juga (Dwijoseputro, 1990). Secara umum tingkat produktivitas yang dicapai oleh seluruh perlakuan lebih rendah dibandingkan dengan deskripsi varietasnya. Hal ini kemungkinan intensitas cahaya di lahan penelitian khususnya dan di Bogor umumnya masih dibawah kebutuhan pertumbuhan optimal tanaman kedelai. Hal ini disebabkan curah hujan yang tinggi dan sering terjadi cuaca mendung berawan.

Perlakuan pupuk memberikan pengaruh yang nyata terhadap bobot 100 butir benih yaitu bobot tertinggi pada perlakuan P5 $(7.40 \mathrm{~g})$ dan bobot terendah pada perlakuan P0 (5.47 g). Bobot 100 butir benih yang tinggi mengindikasikan banyaknya cadangan makanan yang disimpan dalam benih dan sangat penting terhadap pertumbuhan awal benih maupun jika benih disimpan. Bobot 100 butir benih berbeda diduga karena ukuran biji yang berbeda.Ukuran biji merupakan cerminan ukuran tumbuh dan kondisi pertumbuhan tanaman induk di lapangan sehingga diharapkan bobot 100 butir benih yang tinggi mampu menghasilkan tanaman tumbuh 
dengan baik dan mampu berproduksi tinggi di lapangan.

Berdasarkan pada tabel 5 semakin besar bobot 100 butir maka ukuran biji akan semakin besar. Hal tersebut sesuai dengan penelitian Sulastiningsih (2013) menyatakan bahwa ukuran biji dapat mempengaruhi bobot biji. Biji yang terbentuk lebih kecil diakibatkan penuaan dan pemasakan polong terjadi lebih cepat karena ketersediaan asimilat tidak optimal dalam proses fotorespirasi (Fitriana et al., 2008).

Perlakuan P5 memiliki nilai bobot 100 butir benih lebih besar dari semua perlakuan namun tidak berbeda nyata dengan perlakuan $\mathrm{P} 2$, P3, dan P4. Bobot 100 butir benih yang berasal dari P5 memiliki bobot yang paling tinggi karena menyerap unsur hara lebih banyak dengan bantuan mikroba dari PGPR. Selain itu, perlakuan P5 yang menggunakan PGPR lebih tahan terhadap infeksi patogen sehingga tanaman tidak terganggu. Hal ini sesuai dengan pendapat Van Loon et al. (1989) yang menyatakan bahwa rizobakteri dapat menginduksi ketahanan tanaman dengan menginduksi protein sehingga tanaman menjadi lebih resisten terhadap infeksi patogen.

Intensitas serangan hama dan penyakit yang tinggi juga dapat menganggu pertumbuhan dan proses pengisian biji kedelai sehingga tidak penuh dan busuk. hama yang menyerang tanaman fase generatif yaitu Nezara viridula dan Riptortus linearis. Hama ini menghisap polong kedelai yang baru tumbuh sehingga polong menjadi hampa dan biji yang terbentuk tidak penuh sempurna sehingga lebih kecil. Hama ini juga menghisap polong yang sudah berisi penuh sehingga polong dan biji kempis, mengering dan gugur. Hama Spodoptera litura F juga menyerang tanaman kedelai dengan memakan daun kedelai sehingga secara tidak langsung menurunkan jumlah produksi kedelai karena kurangnya fotosintesis. Menurut Suharsono (2011), serangan hama dapat menurunkan hasil kedelai sampai $80 \%$.

\section{Jumlah Tanaman Panen}

Perlakuan pupuk tidak berpengaruh nyata terhadap jumlah tanaman yang dipanen. Perlakuan P0 memiliki persentase jumlah tanaman panen tertinggi tetapi hal ini tidak menjamin produksinya lebih tinggi. Hal ini terjadi karena terdapat jumlah polong yang tidak berisi penuh. Jumlah polong isi paling rendah yaitu P0 dapat dilihat pada tabel 6 .

Tabel 6. Jumlah tanaman panen pada setiap perlakuan pupuk organik

\begin{tabular}{lccc} 
Perlakuan & $\begin{array}{c}\text { Jumlah } \\
\text { Tanaman } \\
\text { Panen }\end{array}$ & $\begin{array}{c}\text { Jumlah } \\
\text { Tanaman } \\
\text { Tumbuh }\end{array}$ & $\begin{array}{c}\text { Persentase } \\
(\%)\end{array}$ \\
\hline P0 & 290.70 & 344.50 & 84.39 \\
P1 & 254.20 & 329.20 & 77.22 \\
P2 & 292.20 & 366.70 & 79.68 \\
P3 & 322.00 & 425.50 & 75.67 \\
P4 & 255.70 & 330.00 & 77.50 \\
P5 & 299.00 & 359.20 & 83.22 \\
\hline
\end{tabular}

Keterangan : Angka yang diikuti huruf yang sama pada baris yang sama menunjukkan tidak berbeda nyata berdasarkan hasil uji tstudent pada taraf 5\%

\section{Pengaruh Penambahan Pupuk Organik terhadap Mutu Fisiologis Benih Kedelai}

Pengujian mutu fisiologis benih terdiri atas dua parameter yaitu viabilitas dan vigor benih. Viabilitas benih yaitu kemampuan benih untuk dapat berkecambah pada suhu dan lingkungan optimum, sedangkan vigor benih yaitu kemampuan benih untuk berkecambah pada suhu dan lingkungan sub optimum. Viabilitas benih terdiri atas DB, PTM, dan BKKN. Vigor benih terdiri atas IV dan $\mathrm{K}_{\mathrm{CT}}$.

Tabel 7. Persentase variabel mutu fisiologis benih pada berbagai perlakuan pupuk

\begin{tabular}{lcccc}
\hline Perlakuan Pupuk & Daya Berkecambah (\%) & Indeks Vigor (\%) & $\begin{array}{c}\text { Potensi Tumbuh } \\
\text { Maksimum (\%) }\end{array}$ & $\begin{array}{c}\text { Berat Kering } \\
\text { Kecambah Normal (g) }\end{array}$ \\
\hline P0 & $93.50 \mathrm{a}$ & 88.75 & 95.25 & 2.54 \\
P1 & $95.00 \mathrm{a}$ & 93.25 & 96.50 & 2.53 \\
P2 & $94.75 \mathrm{a}$ & 92.25 & 94.75 & 2.68 \\
P3 & $94.50 \mathrm{a}$ & 92.25 & 97.50 & 2.36 \\
P4 & $87.25 \mathrm{~b}$ & 84.25 & 98.25 & 2.43 \\
P5 & $93.50 \mathrm{a}$ & 91.25 & 94.00 & 2.34 \\
\hline Uji F & $*$ & tn & tn & tn \\
\hline KK $(\%)$ & 3.12 & 4.50 & 3.12 & 11.72 \\
\hline
\end{tabular}

Keterangan: $*$ berpengaruh nyata pada taraf $5 \%, \mathrm{tn}=$ tidak nyata

Hasil yang tidak berbeda nyata di duga karena proses pemanenan, pengeringan dan pengolahan serta pengujian mutu benih dilakukan secara bersamaan dan tidak ada perlakuan yang berbeda. Selain itu, waktu pemanenan yang tepat sehingga kualitas 
benihnya belum menurun dan masih tinggi. Menurut Hasanah (2017), perlakuan pupuk organik dan pupuk hayati tidak memberikan pengaruh nyata terhadap mutu fisiologis benih disebabkan perlakuan tersebut memberikan pengaruh hanya sampai pengamatan di lahan saja, sedangkan pengaruh perlakuan di laboratorium sudah mulai tidak berpengaruh. Hasil pengamatan terhadap mutu fisiologis benih terdapat pada (Tabel 7).

Berdasarkan tabel 7 pengamatan Potensi Tumbuh Maksimum (PTM) menunjukkan nilai rata-rata perlakuan pupuk organik dan pupuk hayati sebesar 94\%- 98.25\%. Potensi Tumbuh Maksimum (PTM) merupakan persentase dari jumlah kecambah normal dan abnormal. Persentase PTM yang dihasilkan tergolong sangat tinggi. Pengamatan Daya Berkecambah (DB) diperoleh dari persentase jumlah kecambah normal hari hitung 1 dan hari hitung 2 . Pengamatan Daya Berkecambah (DB) memberikan hasil rata-rata pengaruh perlakuan pupuk sebesar $87.25 \%$ - 95\%. Persentase DB tergolong tinggi dimana nilai DB lebih besar dari $85 \%$ (>85\%). Pengamatan Berat Kering Kecambah Normal (BKKN) memberikan nilai rata-rata perlakuan pupuk sebesar 2.34-2.68 g. Berat kering mencerminkan mutu fisiologis benih yang akan berpengaruh terhadap terpenuhinya sumber energi yang cukup (Sadjad et al., 1999). Viabilitas benih yang dihasilkan tergolong tinggi. Menurut Lesilolo et al., (2013), Viabilitas benih yang tinggi akan memberikan perkecambahan yang baik karena sumber energi dari cadangan makanan tersedia.

Pengamatan Indeks Vigor memberikan nilai rata-rata perlakuan pupuk organik dan pupuk hayati sebesar 84.25\%-93.25\%. Indeks Vigor (IV) didapatkan dari penjumlahan kecambah normal pada hari hitung pertama. Hasil IV tergolong tinggi dan baik. Lot benih dengan indeks vigor lebih tinggi akan lebih cepat tumbuh, seragam, dan mampu bersaing dengan gulma (Asih, 2016). Menurut Hasanah (2017), persentase PTM, DB, BKKN, dan IV yang tinggi diduga karena benih yang segar dan tidak ada perlakuan penyimpanan.

Analisis ragam pengaruh perlakuan penambahan pupuk tidak berbeda nyata terhadap indeks vigor benih, potensi tumbuh maksimum dan berat kering kecambah normal tetapi berbeda nyata dengan daya berkecambah (Tabel 7). Perlakuan pupuk organik berpengaruh nyata terhadap daya berkecambah. Daya berkecambah dan indeks vigor tergolong tinggi. Hal ini diduga karena kualitas benih yang masih bagus disebabkan panen dilakukan saat curah hujan rendah yaitu Maret (122.700 $\mathrm{mm})$ sehingga proses pemanenan dan pengeringan tidak tertunda. Menurut Patiroi (1998), pemupukan yang optimal akan memiliki mutu fisiologis benih yang tinggi dan salah satunya ditunjukkan dari tingginya daya berkecambah. Daya berkecambah paling tinggi didapatkan pada P1 (pupuk anorganik) dan tidak berbeda nyata dengan perlakuan lainnya kecuali perlakuan P4 (POC).

\section{KESIMPULAN}

Penambahan pupuk organik meningkatkan produksi biji. Produksi biji paling tinggi dicapai oleh perlakuan P5 (PGPR dengan dosis $10 \mathrm{~g} \mathrm{~kg}^{-1}$ benih) yaitu $993.04 \mathrm{~g}$ petak $^{-1}$ atau 1.10 ton $^{-1}$ meskipun tidak berbeda nyata secara statistik dengan P1 (Pupuk anorganik), P2 (Abu sekam bakar), dan P3 (Bio organik). Penambahan pupuk organik dapat meningkatkan daya pegang tanah sehingga ketersediaan hara dari pupuk anorganik lebih tinggi. Penambahan pupuk organik belum mampu meningkatkan mutu fisiologis benih pada variabel pengamatan daya berkecambah, indeks vigor, potensi tumbuh maksimum dan berat kering kecambah normal.

\section{DAFTAR PUSTAKA}

Adisarwanto. 2008. Budidaya Kedelai Tropika. Penebar Swadaya, Jakarta.

Ai, N.S., M. Ballo. 2010. Peranan air dalam perkecambahan biji. Jurnal Ilmiah Sains, 10(2): 190-195.

Anggraeni, B.W. 2010. Studi agronomi, morfoanatomi dan fisiologi kedelai (Glycine $\max$ L. Merr) pada kondisi cekaman intensitas cahaya rendah. [Skripsi]. Institut Pertanian Bogor, Bogor.

Asih, P.R. 2016. Isolasi, identifikasi, serta aplikasi rhizobakteri dan pupuk nitrogen fosfat dalam mempengaruhi mutu fisiologis benih dan pertumbuhan tanaman tetua betina jagung hibrida. [Tesis]. Institut Pertanian Bogor, Bogor.

[BMKG] Badan Meteorologi, Klimatologi dan Geofisika. 2018. Data Iklim Desember 2017-April 2018. Stasiun Klimatologi Dramaga, Bogor.

[BPTP] Balai Pengkajian Teknologi Pertanian NAD. 2009. Budidaya tanaman kedelai. http://nad.litbang.pertanian.go.id/ind/image s/dokumen/modul/13Brosur_kedelai1.pdf. [8 Juli 2018] 
Dharmaswara, I. 2012. Pengaruh pemupukan abu jerami terhadap pertumbuhan dan produksi kedelai di lahan rawa pasang surut. [Skripsi]. Institut Pertanian Bogor, Bogor.

Dwijoseputro, D. 1990. Pengantar Fisiologi Tumbuhan. Gramedia Pustaka Utama, Jakarta.

Eliazar, T.T., S.A. Aziz. 2015. Guano and ricehull ash application for flowering induction on orange jessamine (Murraya panniculata (L.) Jack). Journal of Tropical Crop Science, 2(3):14-21.

Fitriana, J., K.K. Pukan, L. Herlina. 2008. Aktivitas enzim nitrat reduktase kedelai kultivar burangrang akibat variasi kadar air tanah pada awal pengisian polong. [Skripsi]. Universitas Negeri Semarang, Semarang

Gani, J.S.A., M.I. Bahua, F.Zakaria. 2013. Pertumbuhan DNA hasil tanaman kedelai (Glycine max L.Merril) varietas tidar berdasarkan dosis pupuk organik padat. [Skripsi]. Universitas Negeri Gorontalo, Gorontalo.

Hasanah, I. 2017. Pengaruh dosis pupuk (N,P,K) dan formulasi pupuk hayati terhadap produksi dan mutu benih jagung hibrida di lapang. [Skripsi]. Institut Pertanian Bogor, Bogor.

Hindersah, R., T. Simarmata. 2004. Potensi rizobakteri azotobacter dalam meningkatkan kesehatan tanah. Jurnal Natur Indonesia, 5(2): 127-133.

Jordan, D.C. 1984. Famili III. Rhizobiaceae conn 1938, 321AL, p. 234-256. In N.R. Krieg, J.E. Holt (Eds.). Bergeys Manual of Systematic Bacteriology. The William and Wilkins Co, Baltimore.

[KEMENTAN] Kementerian Pertanian. 2015. Rencana strategis Pembangunan Tanaman pangan tahun 2015-2019. Direktorat Jenderal Tanaman Pangan, Jakarta.

Lesilolo, M.K., J. Riry, E.A. Matatula. 2013. Pengujian viabilitas dan vigor benih beberapa jenis tanaman yang beredar di pasaran kota Ambon. Agrologia, 2(1): 1-9.

Lingga, P., Marsono. 2000. Petunjuk Penggunaan Pupuk. Penebar Swadaya, Jakarta.

Maor, R., S. Haskin, K.H. Levi, A. Sharon. 2004. In planta production of indole-3-acetic acid by Colletotrichum gloeosporioides f. sp. Aeschynomene. Appl Environt Microbiol.
70: 1852-1854. Marsono, P. Sigit. 2000. Pupuk dan Cara Pemupukan. Penerbit Bathara Karya Aksara, Jakarta.

Patiroi, A.R. 1998. Daya simpan benih jagung HC9 dari berbagai kombinasi pemupukan dan kondisi penyimpanan. [Tesis]. Universitas Hasanuddin, Makassar.

Rosmarkam, A., N.W. Yuwono. 2002. Ilmu Kesuburan Tanah. Kanisius, Yogyakarta.

Rukmana, R., Y. Yuniarsih. 1996. Kedelai Budidaya dan Pasca Panen. Kanisius, Yogyakarta.

Sadjad, S., E. Murniati, S. Ilyas. 1989. Parameter Pengujian Vigor Benih dari Komparatif ke Simulatif. Grasindo, Jakarta.

Saraswati, R., Sumarsono. 2008. Pemanfaatan mikroba penyubur tanah sebagai komponen teknologi pertanian. Jurnal Iptek Tanaman Pangan, 3(1):20.

Siregar, S.R., Zuraida, Zuyasna. 2017. Pengaruh kadar air kapasitas lapang terhadap pertumbuhan beberapa genotipe M, kedelai (Glycine $\max$ L. Merr). Jurnal Floratek, 12(1):10-20.

Suminarti, N.E. 2010. Pengaruh pemupukan N dan $\mathrm{K}$ pada pertumbuhan dan hasil tanaman talas yang ditanam di lahan kering. Akta Agrosia, 13(1): 1-7.

Susanto, G.W.A., T. Sundari. 2010. Pengujian 15 genotipe kedelai pada kondisi intensitas cahaya $50 \%$ dan penilaian karakter tanaman berdasarkan fenotipnya. Jurnal Biologi Indonesia, 6 (3):459-471.

Suharsono. 2011. Kepekaan galur kedelai toleran jenuh air terhadap ulat grayak Spodoptera litura F. Suara Perlindungan Tanaman, 1(3):13-22.

Sulastiningsih, N.W.H. 2013. Uji daya hasil beberapa galur kedelai (Glycine $\max \mathrm{L}$. Merril) di Mataram pada dua musim tanam. [Tesis]. Institut Pertanian Bogor, Bogor.

Sumarno, A.G. Manshuri. 2007. Persyaratan tumbuh dan wilayah produksi kedelai di Indonesia. Badan Penelitian dan Pengembangan Pertanian. Pusat Penelitian dan Pengembangan Tanaman Pangan, Bogor.

Sundari. 2015. Pengaruh pemberian abu sekam, P, dan $\mathrm{K}$ terhadap pertumbuhan dan produksi kedelai hitam pada budidaya jenuh air di 
lahan pasang surut. [Skripsi]. Institut Pertanian Bogor, Bogor.

Surtiningsih, T., Farida, T. Nurhariyati. 2009. Biofertilisasi bakteri Rhizobium pada tanaman kedelai (Glycine max L.). Berk. Penel Hayati, 15: 31-35.

Suswono. 2010. Pupuk Bio Organik. Sidomuncul, Semarang. van Loon L.C., P.A. Bakker, C.M.J. Pieterse. 1998. Systemic resistance induced by rhizoshere bacteria. Phytopathology, 88:453-483.

Wahyuni, S. 2009. Pengaruh berbagai konsentrasi pupuk organik cair terhadap pertumbuhan dan hasil tanaman kedelai (Glycine $\max \mathrm{L}$. Merill). [Skripsi]. Universitas Jambi, Jambi. 